\title{
Fenntartható építészet globális kontextusban
}

\section{Globális kihívások}

Az épített környezetünk fenntarthatóságára egyre nagyobb figyelmet kell fordítani, mert az építőiparnak, illetve az épített környezetnek globális szinten is jelentős hatásai vannak. Az ENSZ globális népesedésre vonatkozó előrejelzése ${ }^{1}$ szerint a vidéki, illetve városi életforma 1950 és 2050 között teljesen felcserélődik, és közel 100 év alatt a városi lesz a domináns. Ha figyelembe vesszük a népesség folyamatos növekedését is, nyilvánvaló, hogy a dominánssá váló városi életformával az épített környezet, illetve az építőipar is folyamatosan bővül. Már ma az épített környezet és az építőipar felel a primer energiafogyasztás és a károsanyag-kibocsátás közel $40 \%$-áért ${ }^{2}$, továbbá globálisan és hazánkban is egyre nő a burkolt vagy beépített területek aránya ${ }^{3}$, és ezzel együtt csökkennek a természetes területek. Nyilvánvaló, hogy a klímaváltozás, illetve az emberi tevékenységek okozta negatív hatások csökkentése, és a természeti értékeink és természeti tőkéink megóvása kiemelkedően fontos feladat, amelyben az épített környezetnek és az építőiparnak is kiemelkedő szerepe van.

Mivel az épített környezetünk legnagyobb hányada már meglévő épületekböl áll, erre a területre is kiemelt figyelmet kell fordítani. Az épített környezet fenntarthatósága nemcsak a természeti tőkével és nyersanyagokkal való felelős bánásmódot jelenti, hanem a kulturális értékeink megőrzését és ápolását is. Az építészeti értékeink kulturális kincsünk részét képezik, és nem mellékesen a meglévő épületek ökológiai lábnyoma is általában alacsonyabb, mint egy újonnan épülő zöld beruházásénak.

\section{Nemzetközi zöldépület-minősítések}

Az épített környezet fenntarthatóságát és környezettudatosságát nemzetközileg elismert és hazánkban 2008 óta sikeresen alkalmazott minősítési keretrendszerekkel lehet mérni. Ezen minősítések lehetővé teszik a nemzetközi összehasonlítást, illetve a harmadik fél általi tanúsítást. A minősítés fenntarthatósági ke-

${ }^{1}$ United Nations World Population Prospects, Key findings \& advance tables - 2017 revision, New York, United Nations, 2017, https://esa.un.org/unpd/wpp/Publications/Files/WPP2017_KeyFindings.pdf (2017. november 28.)

${ }^{2}$ Eurostat adatok, http://ec.europa.eu/eurostat/statistics-explained/index.php/Consumption of_energy (2017. november 28.)

${ }^{3}$ KSH A fenntartható fejlődés indikátorai Magyarországon, 2016, Központi Statisztikai Hivatal, 2017, http://www.ksh.hu/docs/hun/xftp/idoszaki/fenntartfejl/fenntartfej116.pdf (2017. november 28.) 
retrendszert nyújt új és meglévő épületek számára, és holisztikus módon méri az adott épület teljesítményét. A minősítések nemcsak az energiahatékonyságra vagy a nyersanyagokkal való tudatos és felelős bánásmódra térnek ki, hanem az emberközpontú szemléletre, az épülethasználók egészségének és jó közérzetének megőrzésére, ami ugyanolyan fontos, mint a felhasznált anyagok minősége és beszerzésük forrása. A minősítések önmagukban nem tudják az épületeket egy csapásra környezettudatossá és fenntarthatóvá varázsolni; ehhez jól felkészült tervezőmérnökök, építészek, épületüzemeltetők és - nem utolsósorban tudatos épülethasználók együttesen szükségesek. Széles körü szemléletváltásra és tudatosságra is szükség van ahhoz, hogy az épített környezetünk ökológiai lábnyoma csökkenjen.

Hazánkban a passzívház minősítés mellett három nagy nemzetközi zöldépület-minősítő rendszert alkalmaznak sikeresen: az angliai, illetve európai gyökerekkel rendelkező BREEAM-et, az amerikai LEED-et és a német DGNB rendszert. Az épületminősítések számát tekintve jelenleg a BREEAM rendszer szerint van hazánkban és a közép-kelet-európai régióban a legtöbb ingatlan értékelve, ezt szorosan követi a LEED minősítések száma. Mostanra az egészséges belső terekre és az épületfelhasználókra egyre nagyobb figyelmet fordítanak a minősítési rendszerek, ezért a LEED mellett megjelent például a WELL minősítés is, amely kifejezetten a belső terekre és a jó közérzet megteremtésére fókuszál.

\section{Hazai pozitív példa}

Bár a 2008-2009-es gazdasági válság a hazai építőipart is súlyosan érintette, mégis számos olyan új ingatlanfejlesztési projekt valósult meg az utóbbi években Magyarországon, amely a környezettudatosságot kiemelt helyen kezelte, és azt nemzetközi minősítésekkel is tanúsíttatta. Paradox módon többek között az építőipar visszaesése lendítette fel hazánkban a zöldépület-minősítéseket: az újépítésü projektek számának erős visszaesése miatt több idő jutott a fejlesztések mélyebb átgondolására, és a hosszú távú fenntarthatósági tényezők integrálására.

A Közép-európai Egyetem (CEU) belvárosi campusának újjáépítésénél és rekonstrukciójánál kiemelt hangsúlyt kapott a fenntarthatóság és a környezettudatosság ${ }^{4}$. Az átfogó fejlesztés elejétől fogva nyilvánvaló volt, hogy az egyetem nemcsak a tervezésnél, de a kivitelezésnél és az üzemeltetésnél is komolyan veszi a fenntarthatóságot. Az épülethasználók (oktatók, diákok) folyamatos oktatása és a környezettudatosság integrálása már évek óta sikeresen zajlik különböző - részben fakultatív - programok keretében, továbbá az egyetem egy átfogó fenntarthatósági keretrendszerrel is rendelkezik, amely nemcsak az oktatásra tér ki, hanem az üzemeltetést és a fejlesztéseket is magában foglalja. A fejlesztési projektek környezettudatosságát a BREEAM minősítési rendszer szerint tanúsíttatták, a meglévő épületrészeket és épületelemeket pedig sikeresen 
integrálták a projektbe. Ez utóbbi nemcsak az épített környezetünk megóvását és tovább használatát jelenti, hanem segít az ökológiai lábnyom csökkentésében is.

Az új egyetemi könyvtár kialakításánál a nyitottság és az átláthatóság ugyanolyan fontos szerepet játszott, mint a felhasznált anyagok minősége és az emberközpontúság. Világos anyagok és burkolatok dominálják a belső tereket, és a nagyobb mennyiségben megjelenő faburkolatoknál és bútoroknál az anyagok beszerzési forrása és a felületkezelő anyagok károsanyag-tartalmának minimalizálása alapvető követelmény volt.

\section{Rezümé}

Mivel az épített környezet jelentős ökológiai lábnyommal rendelkezik, kiemelkedően fontos, hogy az épületeket fenntartható módon tervezzék, kivitelezzék, üzemeltessék és használják. Ezt átfogó szemléletváltással lehet elérni, mely a fenntarthatóság különböző dimenzióit is magába foglalja. A nemzetközileg elfogadott normák alapján kidolgozott fenntarthatósági és környezettudatos keretrendszerek jó eszközei a tudatos épülethasználatnak, mely nemcsak a természeti erőforrásokra vonatkozik, hanem a társadalom egészére és az emberre is. A fenntarthatósági aspektusokat a Közép-európai Egyetem campusfejlesztési projektje keretében sikeresen integrálta, és egy nyitott és egészséges felsőoktatási műhelyt teremtett meg Budapest belvárosának szívében.

\section{Sustainable architecture in a global context}

As the built environment's ecological footprint is significant, it is important to design, construct, manage and use buildings in a sustainable way. This can be achieved with a comprehensive knowledge transfer, which includes all dimensions of sustainability. The internationally established sustainability schemes and systems provide a good framework for the building users and are not only related to natural resources, but include social and human aspects as well. The sustainability aspects were successfully integrated into the campus redevelopment project of the Central European University, and such as an open and healthy environment was created for higher education in the heart of downtown Budapest.

BARTA ZSOMBOR elnök Magyar Környezettudatos Építés Egyesülete 